BACTERIOLOGICAL NOMENCLATURE AND

TAXONOMY

Volume 5

October 15,1955

No. 4

\title{
SOME OBSERVATIONS UPON THE STATUS OF THE GENERIC NAME SELENOMONAS PROWAZEK
}

\author{
A.E. Oxford \\ Rowett Research Institute \\ Bucksburn, Aberdeenshire, Scotland
}

The following observations are in favour of Draft Proposal Alternative 2 and against Alternative 1 (Judicial Commission, 1955). A good case can be madé out for regarding the generic name Selenomastix, conferred by Woodcock and Lapage (1913) on certain goat rumen organisms, as invalid by reas on of uncertainty. As all later students of rumen microbiology have confirmed (cf. McGaughey and Sellers, 1948) there were at least two morphologically distinct organisms described by Woodcock and Lapage, to which the name Selenomastix was indiscriminately applied by these authors; and although they usually occur together in the rumen, no one has yet shown that a relationship of any sort exists between them. They are in fact very different in many respects. Thus, one resembles Selenomonas palpitans from the guinea pig caecum (see Lessel and Breed, 1954) in being crescentshaped and motile by a group of lateral flagella; the other is purely oval in shape and is never flagellated. Nevertheless it is indisputably motile upon occasion. Unlike the crescents, the ovals have a visible cell wall or envelope. The yeast-like glycogen-storing organisms studied by Quin (1943) consisted entirely of the latter, as his description and photomicrograph clearly show. Since the excellent photomicrographs of the caecal Selenomonas palpitans in Lessel and Breed (1954) show only a crescent form, never an oval, there is no warrant by analogy for assuming that the rumen ovals might be one stage in the life cycle of an organism which may also exist at another stage in its life history as flagellated crescents. In fact Woodcock and Lapage noted that one form might be rare and the other plentiful in a given rumen. In the rumen, therefore, it would be safer to regard them as two distinct organisms and since the rumen crescents might

(Page 131) 
legitimately be placed in the genus Selenomonas, it is arguable that the rumen ovals, studied by Quin and called by him Schizosaccharomyces ovis, might legitimately be named Selenomastix ruminantium (Woodcoek and Lapage, 1913) since these authors did apply that name to the rumen ovals as well as the crescents. Whatever else the ovals may be they are certainly not yeasts (see van der Westhuizen and Oxford, 1950, and pace McGaughey and Sellers (1948). I would say that they have not yet validly been named. If subsequent investigation should reveal a real relationship between the rumen crescents and ovals, the above conclusion would, of course, need revision.

\section{REFERENCES}

Judicial Commission. Status of the generic name Selenomonas von Prowazek. Int. Bull. Bact. Nomen. Tax. 5: 7-11. 1955 .

Lessel, E.F. Jr. and R.S. Breed. Selenomonas Boskamp, 1922 - a genus that includes species showing an unusual type of flagellation. Bact. Revs. 18:165-167. 1954.

McGaughey, C.A. and K.C. Sellers. Microflora of the rumen. Nature (London) 161:1014-1015. 1948 .

Quin, J.I. Studies on the alimentary tract of merino sheep in S. Africa VII - Fermentation in the forestomachs of sheep. Onderstepoort Jour. Vet. Sci. 18:91-112. 1943.

Van der Westhuizen, G.C.A. and A.E. Oxford. Studies on the alimentary tract of merino sheep in S. Africa. XVI. On the identity of Schizosaccharomyces ovis. Onderstepoort Jour. Vet. Sci. 24:119-124.1950.

Woodstock, H.M. and G. Lapage. On a remarkable type of protistan parasite. Quart. Jour. Micro. Sci. N.S. 59: $431-458.1913$. 